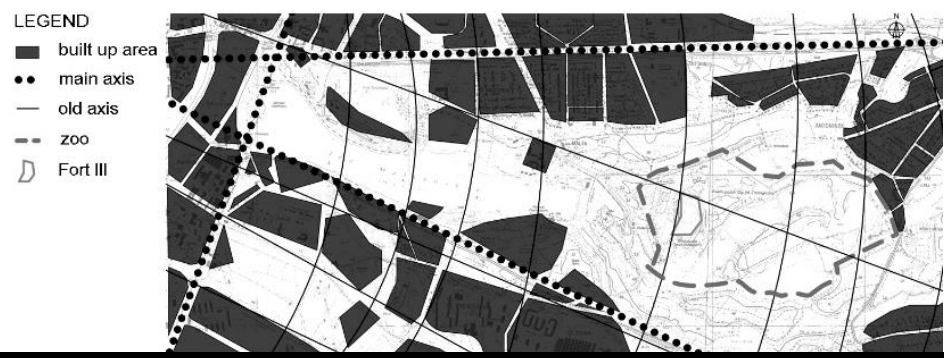

DOI: 10.21005/pif.2021.47.C-03

\title{
REVITALIZATION OF THE AREA OF FORT III GRAF KIRCHBACH AS AN ELEMENT OF RESPONSIBLE URBANIZATION OF THE CITY OF POZNAŃ
}

REWITALIZACJA OBSZARU FORTU III GRAF KIRCHBACH JAKO ELEMENT ODPOWIEDZIALNEJ URBANIZACJI MIASTA POZNAŃ

\author{
Izabela Piklikiewicz-Kęsicka \\ Mgr inż. Arch. \\ Author's Orcid number: 0000-0002-5370-9027 \\ Politechnika Poznańska \\ Wydział Architektury \\ Instytut Architektury i Planowania Przestrzennego
}

\begin{abstract}
The paper aim is to examine urban and spatial possibilities of the Poznań Fort III area in the context of the implementation of the city's spacial policy. Urbanisation based on executing new facilities and investments results in the creation of diverse urban landscape. This contrast concerns not only the visual perception, but also also uneven use of different parts of the city. The aim of the study is to present a strategy for the revitalisation of the Fort Graf Kirchbach in the accordance with the principles of responsible urbanisation.
\end{abstract}

Key words: forts, public space, responsible urbanization, revitalization.

\section{STRESZCZENIE}

Celem artykułu jest zbadanie możliwości urbanistycznych i przestrzennych obszaru poznańskiego Fortu III w kontekście realizowania polityki przestrzennej miasta. Urbanizacja opierająca się na realizowaniu nowych obiektów i inwestycji powoduje powstawanie zróżnicowanego krajobrazu miejskiego. Omawiany kontrast dotyczy nie tylko odbioru wizualnego, ale również nierównomiernego użytkowania poszczególnych części miasta. Badania mają na celu przedstawienie strategii rewitalizacji terenu Fortu Graf Kirchbach zgodnie z zasadami odpowiedzialnej urbanizacji.

Słowa kluczowe: forty, odpowiedzialna urbanizacja, przestrzeń publiczna, rewitalizacja. 


\section{INTRODUCTION}

Contemporary urban planning undeniably encounters the present planning problems often resulting from the consequences of actions and decisions taken in the past. This is the situation in the case of activities aimed at modernization and expansion of the urban plan in the face of respect for the presence of historically valuable objects and those under conservator's protection. Problems of this type can be qualified to different scales in terms of the impact of the historical area on the surrounding urban structure. In the case of stand-alone facilities, which do not form axes and urban compositions, planning activities related to the implementation of urban development programmes seem to be possible to implement. A more complex situation occurs as a result of an attempt to expand or modify an urban structure having objects or groups of objects strongly integrated on a large scale into the urban plans. An example of such a city structure is the city of Poznań, which has fortification remains from the nineteenth and twentieth centuries (Biesiadka J. et al, 2006). Planned on a circular plan, they still dominate in a visible way in the urban layout of the city. The scale of even a single fortress layout does not allow to underestimate it in the process of developing and modernization of the city.Undeniably, the size of the area occupied by Poznan forts constitute an area touching upon the problems on a scale not only architectural but also urban.

During the development of the polisch city, one of the main documents leading and determining architectural, investment and planning activities is Studium Uwarunkowań I Kierunków Zagospodarowania Przestrzennego Miasta (the Study of Conditions and Directions for Spatial Management of the City). The aim of the management is to shape and present the objectives and vision of future urban planning. One of them in the vision of the city of Poznan is the creation of a metropolitan city based on the development of knowledge (Spatial Management of City of Poznan, 2014). The attempt to achieve the objectives listed in the document undeniably collides with the problem of fortification residues. The aim of the article is to present the problem of shaping future urban planning, which in its history was connected with military architecture on the example of the city of Poznan and Malta district. This part of the city contains in its structure the remains of Fort III Graf Kirchbach (Biesiadka J. et al, 2006). The fort is one of the eighteen forts that testified to the presence of one of the largest fortresses in Poland.

\section{AIM OF THE RESEARCH}

The research area is located in the eastern part of the city and is very well communicated with its central part. The Poznań Fort III area is connected to the market square by means of communication between these two parts of the city through Małe Garbary, Estowskiego, Wyszyńskiego and Warszawska streets. The aforementioned streets run in a horizontal west-east line, forming a planning axis broken by Krańcowa Street, which directly connects with the discussed fortress. This type of urban arrangement can initiate new planning opportunities for the development of the city in accordance with its strategy by respecting historical values and their testimony. The aim of the research is to detect possible directions of activities with the use of post-fortification residues in order to develop urban space, create an attractive functional offer for residents and create a unique urban zone. The results of the research are intended to contradict or confirm the thesis concerning the identification of potential project guidelines used in the revitalisation of areas with an area of more than a few hectares.

The significant position of the remains of Poznan military architecture is not only manifested in the current plans of the city, but is also closely related to Polish history. It is a testimony of historical legacy. It is an authentic source of architectural, engineering and technical knowledge. The inventory of Fort III (Piklikiewicz-Kęsicka I., 2017) shows the state of preservation of the historical substance, which makes it possible to get to know and understand the art of military buildings. This means that the fortress remains are undeniably no longer just an element of the urban structure, but should be properly prepared and made available to the widest possible audience. Paradoxically, one of the most characteristic military architectural features - hiding - is one of the difficulties in striving to emphasize and make the discussed object visually more attractive. The purpose of the fortress buildings was primarily to mask the object from the enemy. Location in a strongly wooded area, covering with 
soil, earth embankments and walls even today merge visually with the natural landscape. Any actions taken in order to physically expose the object interfere with the need to preserve fortresses and embankments, which are also an element of the valuable assumption of the protected monument. Interference in their arrangement would certainly be destructive and disturbing the whole of the authentic fortress architectural plan. All the more so, engaging not only the object itself in revitalization and conservation activities, but also urban planning including communication and composition systems seem to be the right step to actively include the remains of this valuable object in the developing city space.

\section{RESEARCH METHODOLOGY}

In order to illustrate the research issues, the methodology of analysis and logical construction research was used (Niezabitowska E., 2014). It was used to graphically analyze the Poznan area of Malta in terms of selected urban and planning factors. The research focuses mainly on diagnosing urban directions using the historic military architecture of Fort III. The area under development was subjected to walkthrough studies, which made it possible to carry out on-site and inventory urban inspections. Historical and literary research confirmed the validity of the searched activities and directions. The article presents examples of objects and urban space, whose historical genesis was used to satisfy the needs of the modern user. Selected architectural examples are works of a unique historical genesis, which guaranteed them the creation of an extraordinary urban and public space. The originality of the presented objects does not result from the subjective preferences of the designers, but it is a re-use of architecture, which used to be an important city function and a real testimony of authentic architectural thinking in the past. Places, whose historical conditions ensure originality and lack of false imitation have been created by giving them a new function and adapting them to contemporary urban space.

\section{RESEARCH RESULTS}

Fort III is located in the Poznan region of Malta, at 81 Krańcowa Street. The facility is located within the boundaries of the New Zoo. The spatial area is covered by the local spatial development plan (Poznan City Council , 2002). The document takes into account the adaptation of the fort for the functions of recreational services or for the needs of the zoo. Any planned changes must be agreed with the conservation authority. The local plan allows the fortress to be used for new functions. The vast area occupied by the fort is protected by low and high green areas, which also results from its location in the Natura 2000 protected area. Intervention in greenery in order to expose and emphasize the fort's shape is practically impossible. In addition to the necessary actions to remove the destructive greenery, the fort should remain in its natural cover. Treatments aimed at making the fortress and adjacent space more attractive should therefore refer not only to the facility itself, but also to a wider scope of planning.

The urban analysis of this area in terms of land use, confirms the urban alienation of Fort III from functionally linked areas. Apart from the location of the facility in the service area of the Zoo, the monument is separated from the nearest residential, commercial and recreational areas. An object surrounded by undeveloped greenery does not encourage potential users. Increasing the attractiveness of Krańcowa Street and functional conecting it with the sporting area of Malta could be an appropriate direction in order to emphasise the protected monument in urban planning. Such action would positively extend the recreational area in this part of the city with an additional cultural function, which would be carried out by fort III. The close proximity of Lake Malta and sports facilities would have a chance to continue on an urban level. Currently, the area is connected with Fort III also through the seasonally functioning Maltanka railway. 


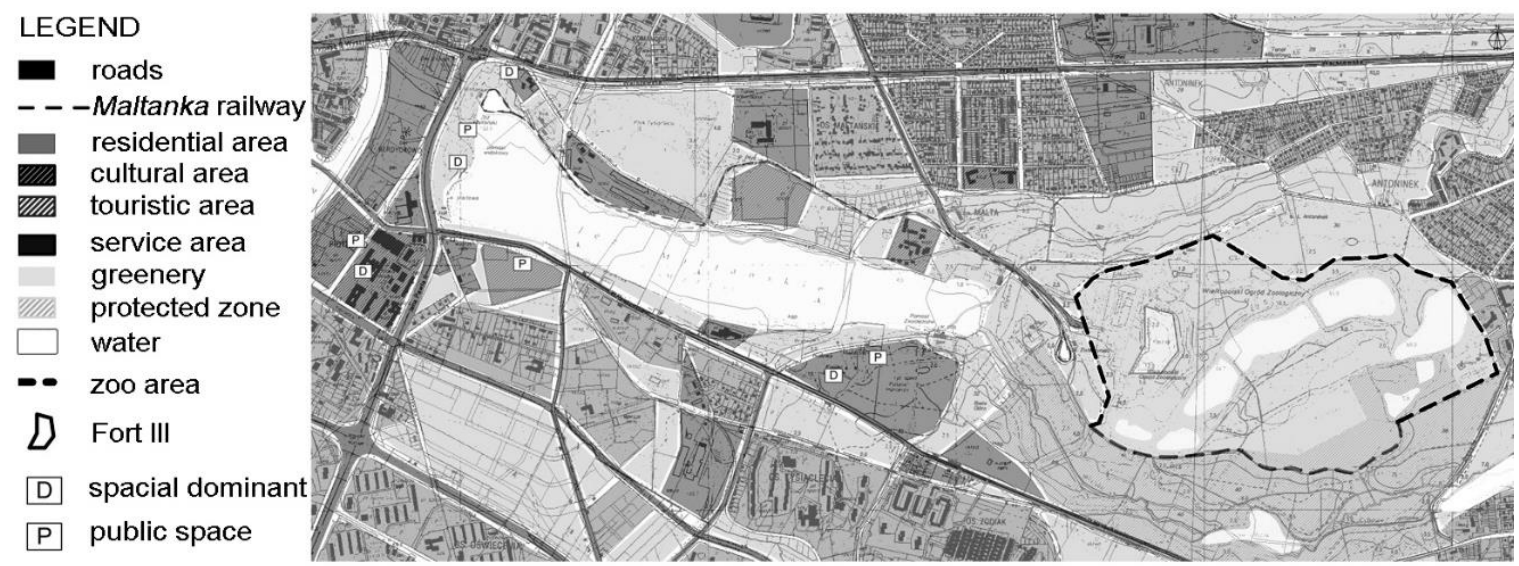

Fig. 1. Functional analysis of the Malta area. Source: own elaboration

Ryc. 1. Analiza funkcjonalna obszaru Malta. Źródło: opracowanie własne

The benefits from the surroundings of the studied area through large areas of high and low greenery are not sufficiently exploited. Inventory studies show the effect of destructive greenery on the grounds of Fort III Graf Kirchbach (Piklikiewicz-Kęsicka I., 2017). Elements of plants and trees that grow uncontrollably interfere with the historic substance of the object and, as a consequence, cause its cracking. A supervised on-site vegetation control is required. Within existing pedestrian and road routes, the possibility of introducing elements of small architecture should be considered. Such a procedure would certainly contribute to intensifying the use of this part of the city and enriched it with visual values. Location of benches and seats would allow users to rest along the route of Lake Malta leading to the fort and along Krańcowa Street. The visual appeal of the street should also be related to the extension of its functional offer. This conclusion is confirmed by Studium Uwarunkowań I Kierunków Zagospodarowania Przestrzennego Miasta Poznań (the Study of Conditions and Directions of Spatial Development of the City of Poznań) [Spatial Management of City of Poznan, 2014] in the drawing attachment covering the service and sports functions located in green areas (Fig. II. 2. 2. 4/4). The implementation of these activities would certainly have a positive impact on the area surrounding the fort and would constitute an urban prelude leading to the protected monument.

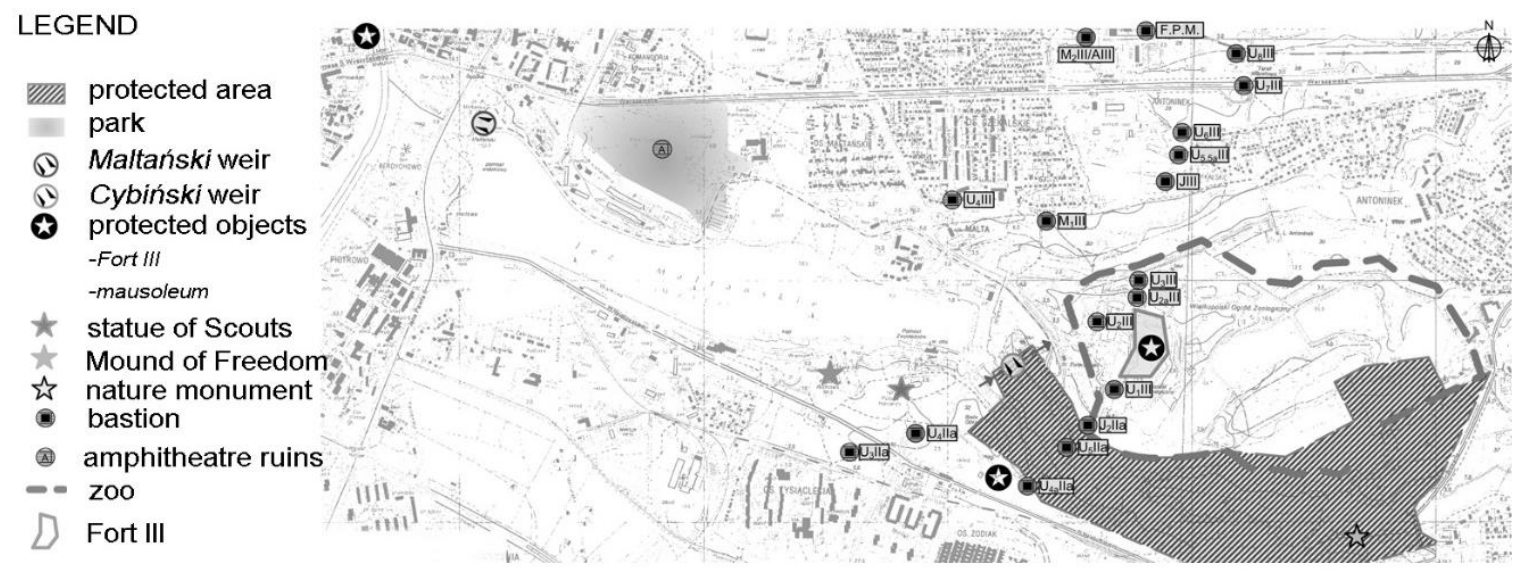

Fig. 2. Historical analysis of the Malta area. Own elaboration

Ryc. 2. Analiza historyczna obszaru Malta. Źródło: opracowanie własne 
The area adjacent to Fort III in the Lake Malta area was assessed as well connected. Access to the monument is made possible through Krańcowa Street, both through the movement of passenger vehicles and public bus transport (line no. 184). There is a two-way bicycle path along the street in question. There is also a collision-free and separate pedestrian path. As a result of the research of the area, no elements allowing the potential user of the historic building to stop and rest, which could be provided by the previously discussed benches or seats, have been observed.

The examined part of the area of Malta has not only a fort as the only protected element of historical value in the area under study. Planning assumptions related to the design of the Poznan military architecture of the outer and inner ring dominated and prioritised the urban planning of the 19th and 20th century city. The area where forts and related buildings were located surrounded and formed the border of Poznań, which has nowadays been surpassed by urban development determined by housing, transport, and economic needs. Despite the intensive development of the city, some elements of these great assumptions have been preserved to this day. In addition to fortresses, there are also bastions, monuments and buildings symbolizing freedom. The remnants of these objects make it possible to create a coherent urban plan, which could form an area that exposes the described monuments to historical value.

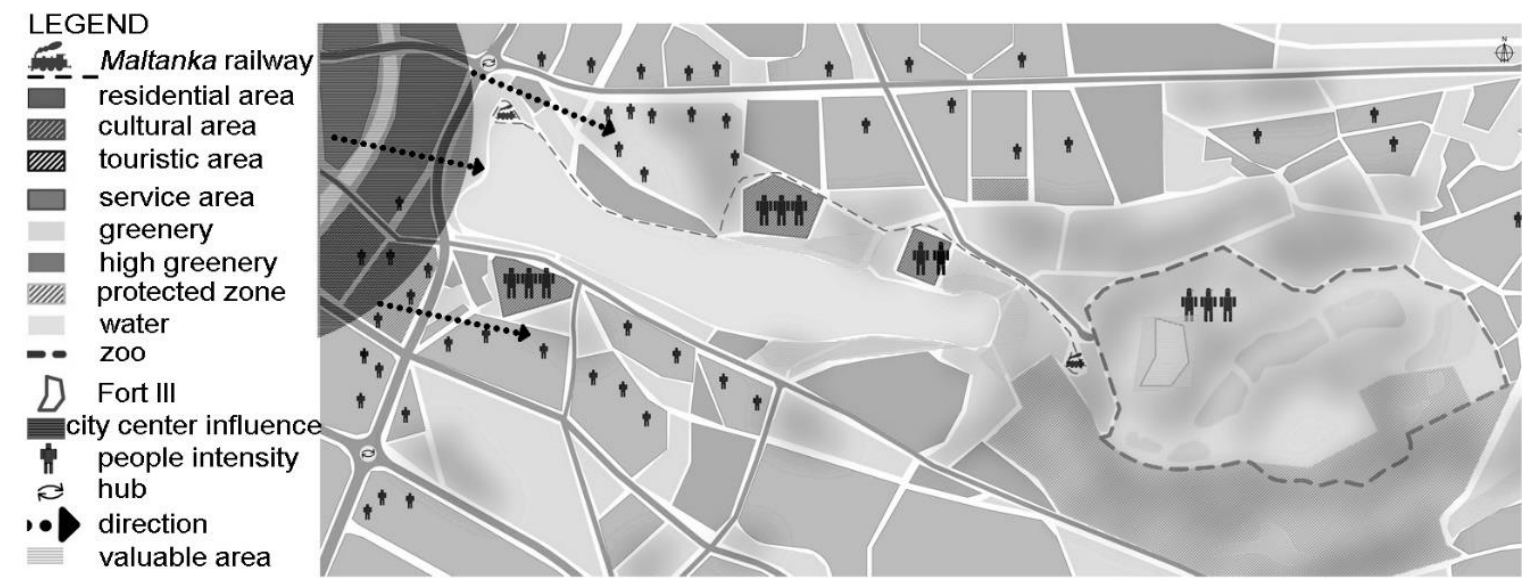

Fig. 3. Conclusions of the analysis of the Malta area. Source: own elaboration

Ryc. 3. Konkluzje z analiz obszaru Malta. Źródło: opracowanie własne

The analysis of the examined area in terms of the intensity of use is strictly dependent on the possibility of all-year-round use of facilities located in this area. Research shows that public spaces with service or recreational functions are the elements marked by the strongest exploitation. Shopping and service centres such as Galeria Malta, the Old Market Square and the Malta Thermal Baths are places that are attractive to potential users of the Malta area. The Old Market was included in the research area because of its good communication with the area under examination, and the fact that it is one of the main tourist attractions of the city. It is a place that should be the beginning of an urban plan to revitalize and urbanize the Fort III area.

Studies of the modern urban plan of Malta have shown the imposition of two model grids shaping the current communication and development of the area (fig. 4.). The first urban grid - radiant - results from historical plans, which were strongly marked in the contemporary layout of the city. The second grid resembling the orthogonal system is the result of actions aimed at communicating the city between its individual parts and adjacent agglomerations. Malta is located on the communication axis between the city centre and the road leading to the city of Swarzedz and route 92 . It is a very attractive area in terms of location, communication and landscape values. 


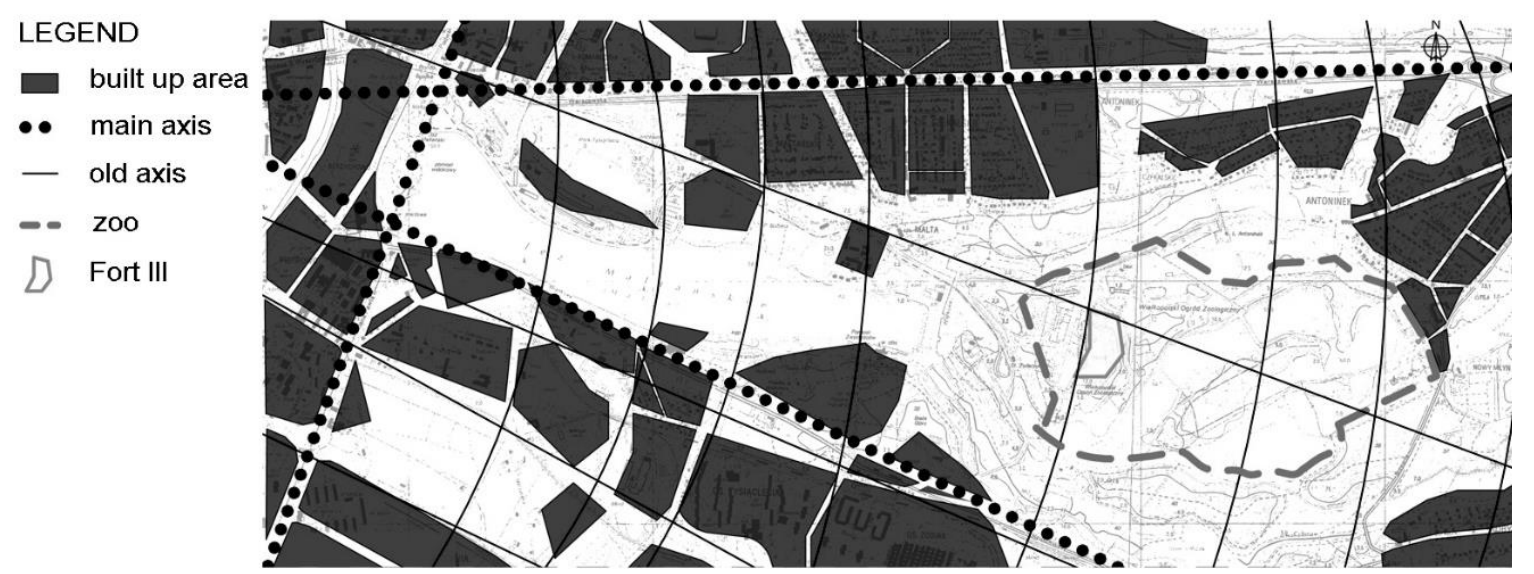

Fig. 1. Compositional axes of the Malta area. Source: own elaboration

Ryc. 4. Osie kompozycyjne obszaru Malta. Źródło: opracowanie własne

Fort III with its location in the Poznan region of Malta is characterized by a good location and communication with the city centre and nearby agglomerations. This is an important factor in the process of merging the historic protected area with the existing urban grid of the city. The surveyed area has features that make it possible to enrich the current functional offer of the city on the basis of historical values. However, it requires not only the revitalization of the monument itself, but also the surrounding areas. Strong intensity of the neighbouring green areas should be developed and modernised in order to create a visually and functionally attractive space for local users and tourists. The area of activities should be extended so as to smoothly unite it with the city centre by means of axial compositions with elements of small architecture and dominant features. The area should be functionally diversified in order to be able to meet the needs of the largest possible number of people. Striving for urban balance by shaping recreational, residential, service and public spaces, spread along an axis, the crowning element of which would certainly be fort III, would be one of the processes aiming at responsible urbanization.

\section{POTENTIAL OF THE FORT III AREA}

The results of the research show the attractiveness of the fortress area located in the region of Malta. Excellent public transport ensures user access to the facility and the surrounding area. The immediate vicinity of recreational areas within the Malta Lake and the possibilities offered by the extensive green areas may constitute the foundation for the creation of an attractive and unique space. After proper preparation and commissioning, it could create new conditions creating the process of bringing the historic fort III to modern use. The unique military architecture, which has been preserved in a form that makes it possible to read its original purpose and the entire design process, is a reliable testimony to military design engineering. It is undeniably an important source of knowledge about architecture and construction. This space does not only involve walls and rooms, but also precise shaping of the terrain and greenery. This huge spatial assumption gives many opportunities for contemporary design in the field of revitalization of historic areas. The close location of the city centre and functionally attractive areas adjacent to Fort III ensures the inflow of potential users into this part of the city. Among the surrounding residential, commercial and recreational areas, the fortress could harmonise the functional programme of the Malta area and enrich its inhabitants and tourists with a unique cultural area.

\section{EXAMPLES OF REVITALIZATION OF LARGE-AREA OBJECTS}

The aim of the literature research is to refer to examples of revitalisation of urban zones that involved large areas and significantly interfered with the planning structure of the city. In the past, performing 
important functions related to various activities such as defence or transport, they ceased to fulfil their original purpose as a result of civilisational and technical progress. Their role in the functional plane has definitely come to an end in the face of the utility needs of contemporary inhabitants of a given locality. The area they occupied was transformed in order to meet the conditions of spatial planning development strategies. Selected examples of these areas present the use of the potentials of large scale architectural remnants and their transformation into public use in order to shape a unique space for the benefit of modern mankind.

The High Line Park [Cilento K., 2009] in New York is a real example of responsible urbanization. The described assumption is a park stretching nearly $2.5 \mathrm{~km}$ long and raised to a height of about $9 \mathrm{~m}$ above the main horizontal traffic plane. The facility was built in 1930 in a steel structure and performed the function of railway transport over a distance of $21 \mathrm{~km}$ (Żywiałkowski M., 2016). After the collapse of the railway companies, the southern part of the route was demolished and definitively stopped being used. The High Line is an interesting architectural concept in terms of space, which is not only characterized by the elevation of the traffic plane, but also by the layout between the surrounding buildings. With time, the remains of the object began to grow into uncontrolled greenery and constitute an element generating a negative and dangerous public space. In 2003, as a result of an architectural and urban competition, a concept for revitalization of the described area was selected, which proposed the creation of a city park. The authors are designers from James Corner of Field Operations and Diller Scofidio + Renfro. The project included the creation of a space with elements of small architecture and conditions to admire the surrounding landscape. The main attraction is the views of the Hudson River and the characteristic skyscrapers. In the area, cultural zones were also designed for temporary shows and performances. The project was carried out in stages between 2006 and 2014. Unique use of space and giving it a new function, corresponding to the needs of contemporary users, resulted in the creation of this characteristic and unique public space. Probably, had it not been for the historical conditions, an object of this type would never have been created. The described High Line Park is a proof of the possibilities resulting from the skillful use of a nonfunctional facility today by giving it new functions and the use of large-scale urban tools. The project was planned and carried out for the whole multi-kilometre space, which guaranteed the creation of a zone coherent and harmonious with the constantly developing urban planning of the city of New York.

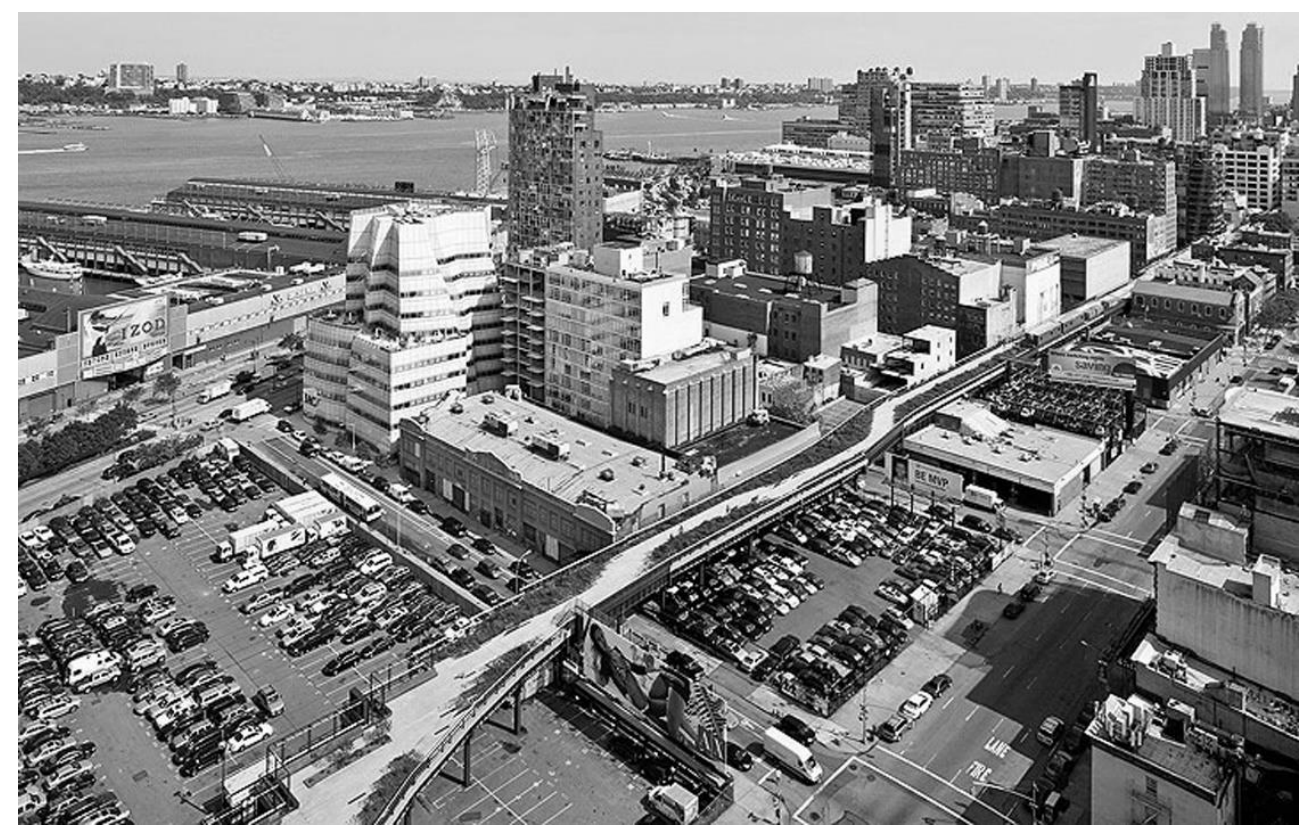

Fig. 2. The High Line Park. Source: The New York High Line officially open

Ryc. 5. High Line Park. Źródło: The New York High Line officially open 
The revitalisation of a given area is divided into the implementation of activities on many levels. Apart from the need to prepare an architectural and conservation database on a examined area, it is extremely valuable to know the opinions and preferences of a local community, which is to be the target recipients of the planned investment. Activities aimed at restoring the functionality of a facility or a group of facilities spread over several hectares is a challenge involving creative and multidirectional design processes. On the other hand, one of the determinants of the success of a given architecture is certainly its proper and constant functioning. This means that the main purpose of revitalisation is to ensure and restore the use of the area under development together with the functional zones located in the neighbourhood. One of the basic urban functions necessary for life are housing functions together with additional areas supporting their use. An excellent example illustrating that issues is the project of the design studio MVRDV, located in Mannheim (Germany). The investment has not yet been completed. The authors have created a 41 ha design assumption for the revitalization of former barracks of the American army (Lynch P., 2017). The idea of the project includes the preservation of existing military buildings and the construction of two modern multi-family residential buildings. This activity guarantees the preservation of the original urban plan and layout of the army buildings, while creating a new architectural structure. The factor integrating the whole revitalized area is the composition axis, systematizing the space and determining the main communication route. The functional program provides for a variety of multi-family and single-family housing typologies. In addition to residential areas, the area also includes service zones, commercial zones and public spaces supporting the interaction between future residents. The main commercial and service zone is located inside a hill located on the compositional axis.

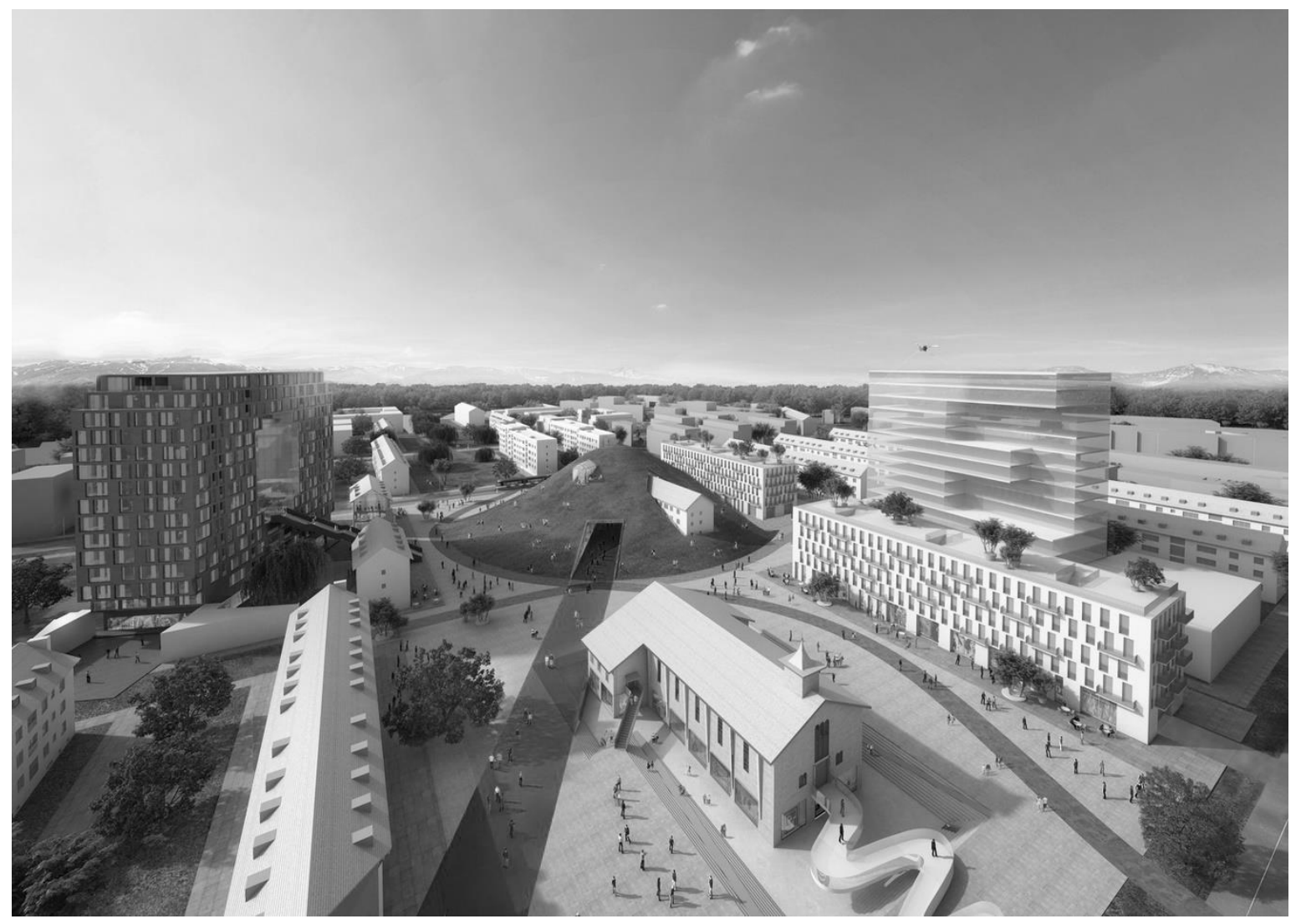

Fig. 3. MVRDV's project for Former Barracks. Photo source: MVRDV's 'H-O-M-E' Ryc. 6. Projekt MVRDV dla byłych koszar. Żródło: MVRDV's 'H-O-M-E' 
The project of MRDV perfectly demonstrates the art of design with respect for historical substance and skilful architectural dialogue between historical buildings and the introduction of a completely new structure. However, the pursuit of this type of activity requires the use of urban tools and a broader perspective on the revitalised area. Single treatments, which are not the result of a comprehensive plan and do not take into account the context of the contemporary urban plan may not guarantee the desired revitalisation effects. Restoring the effective use of the developed area, which does not satisfy the functional needs of the present and future users, requires compatible planning, striving to bring together the new and historic urban structure. For this purpose, responsible urban design and spatial planning is essential, taking into account not only the revitalisation area itself, but also the surrounding area.

One of the largest revitalised areas in Poznan is the Citadel Park with an area of 100 ha. Located in the northern part of the city, it is an interesting example of regeneration of large areas. The park was created within the area containing the remains of the Winiary Fort. This area is an extremely valuable cultural heritage, which has been transformed and now also represents works of art and monuments created from the post-war years to contemporary exhibitions. Despite the demolition of the fort, some elements have survived and were used for surfaces presenting war art. The park is also the burial site for veterans of the January Uprising, Polish Heroes and British soldiers. In addition to the overall exhibition space and commemorating historical events, the area is an original recreational space actively used by the residents. The functional programme of the area was organized in four thematic sectors related to fun and sport, culture, nature and history. In the park there are playgrounds, gyms, theme gardens, museums and a restaurant. The area is an interesting route for skaters and cyclists. The Citadel Park is undoubtedly an original place in the city space, containing the science of Polish history, presenting it in a true post-fortal space. The adaptation of this area to the contemporary needs of the inhabitants has certainly been realized. Comprehensive, coherent and consistent development of this area together with the preservation of original historical remains and the introduction of modern elements guaranteed the creation of a valuable public space that serves the residents and tourists.

Table 1. Example of revitalisations and actions taken on large urban structures

Tabela 1. Przykłady i działania rewitalizacji na wielkopowierzchniowych obszarach urbanistycznych

\begin{tabular}{|l|l|}
\hline Example of revitalisation & Actions taken \\
\hline $\begin{array}{l}\text { High Line Park, NY } \\
\begin{array}{l}\text { Architects: James Corner of Field Operations and Diller } \\
\text { Year: } 2003\end{array}\end{array}$ & $\begin{array}{l}\text { Assigning a new function; adaptation and integration of } \\
\text { functions with the contemporary functional-utility structure } \\
\text { of the neighbouring area; creation of public space - } \\
\text { squares, seats, meeting places, viewing areas; arranging } \\
\text { and caring for existing greenery; installation and design of } \\
\text { modern small architecture of high aesthetic value; lighting } \\
\text { installation; hardening of traffic routes }\end{array}$ \\
\hline $\begin{array}{l}\text { Architects: MVRDV } \\
\text { Year: } 2017\end{array}$ & $\begin{array}{l}\text { Upgrading the area by adapting existing buildings and } \\
\text { building new housing; complementing the residential func- } \\
\text { tion with service and commercial functions, public and inte- } \\
\text { gration spaces; merging the new with the old through a } \\
\text { dominant urban compositional axis }\end{array}$ \\
\hline $\begin{array}{l}\text { The Citadel Park, Poznan } \\
\text { Architect: many authors i.a. Bernard Lisiak } \\
\text { Year: since 1961 }\end{array}$ & $\begin{array}{l}\text { Assigning a new function; integration of functions with } \\
\text { green wedges in Poznań; the release of the military site for } \\
\text { use by residents; creation of a large-scale green structure } \\
\text { in the city centre; giving additional functions: cultural-edu- } \\
\text { cational and gastronomic; providing space for contempo- } \\
\text { rary art; creation of an extensive recreational area }\end{array}$ \\
\hline
\end{tabular}

\section{SUMMARY}

The results confirm the thesis that there are standard design rules supporting large-scale revitalisation activities. It is based on extracting the potential not only from the historic building itself, but also from the surrounding area. The use of spatial planning covering the buffer area, connecting the revitalised area with the contemporary urban structure is the correct direction in restoring the functionality 
of an unused monument. This requires, first of all, a thorough analysis of the appropriate space size. In order to achieve positive conclusions supporting future design processes, the examined object should be developed in terms of relations with the adjacent area. The identification of positive and negative features can form the basis for the pursuit of sustainable design and responsible urbanisation. It also involves the ability to preserve the identity of a given place with the inevitable planned architectural activity (Jarecka-Bidzińska E., 2020). Such action can also be a catalyst for improving the local economy and generally improving the quality of life and functioning in a given settlement structure. To this end, revitalization activities should respond to the current and future needs of the residents (Dudek M., 2019).

The history of civilization has left its mark not only on architectural forms, but also on urban and spatial planning. Such a legacy is part of cultural heritage (Obuchowicz R., 2019). Revitalization of degraded spaces for new purposes should be carried out with respect and emphasis on cultural heritage, which can also be achieved by introducing new architectural forms. In order to achieve a balance between new and historic development, it is necessary to have an in-depth understanding of the site's original setting, its functional and architectural layout.

In the context of revitalizing the Poznan Fort III, it is necessary to consider the way of connecting the monument with the contemporary urban space. Actions to involve the fort in the functional programme of the city, should take place with the participation of a comprehensive use of the potential of the Malta area. The analyses carried out in the area in question show significant spatial, location and functional values, which may constitute a foundation in the revitalisation processes of this extremely valuable military architecture object. The use of good communication of the fortress area, with the city market through the axial and guiding composition, is also an opportunity for Warszawska Street and the surrounding residents to enrich the area with additional service and cultural functions. This area can be used to support the urban flâneur (Paetzold H., 2008) phenomenon. Poznan in terms of urban landscape values is not only limited to the market square itself, but also has interesting districts such as Ostrów Tumski with Cathedral, Śródka and Malta. All these districts are located on the axis leading from the city centre to Fort III. The functional and visual improvement of this territory could become a platform for urban walks with the possibility of their continuation in a recreational space in the area of Lake Malta. The involvement of the user enjoying the attractions of the city centre through movement on this axis, enriched with small architecture and service functions would be a valuable strategy in the process of revitalizing Fort III Graf Kirchbach. The remains of military architecture are not only physical remnants of walls, ruins and bastions. It is an invaluable source of authentic architectural knowledge and a testimony of history, which should be nurtured and made available for broadening and developing knowledge. In the case of large areas, it is responsible urbanisation that determines the survival and quality of our past and, in this case, the future as well.

\section{REWITALIZACJA OBSZARU FORTU III GRAF KIRCHBACH JAKO ELEMENT ODPOWIEDZIALNEJ URBANIZACJI MIASTA POZNAŃ}

\section{WPROWADZENIE}

Współczesna urbanistyka niezaprzeczalnie spotyka się z teraźniejszymi problemami planistycznymi często wynikającymi z konsekwencji działań i decyzji podejmowanych w przeszłości. Taka sytuacja ma miejsce w przypadku aktywności dążących do unowocześnienia i rozbudowania tkanki miejskiej w obliczu poszanowania obecności obiektów cennych historycznie i objętych ochroną konserwatorską. Problematykę tego typu można zakwalifikować do różnej skali pod względem oddziaływania obszaru historycznego na otaczającą go strukturę urbanistyczną. W przypadku obiektów samodziel- 
nych, które nie tworzą osi oraz kompozycji urbanistycznych działania planistyczne związane z realizacją programów rozwoju miast wydają się być możliwe do wdrożenia. Bardziej skomplikowana sytuacja następuje w wyniku próby rozbudowania lub modyfikowania struktury miejskiej posiadającej obiekty lub zespoły obiektów silnie scalonych w sposób wielkoskalowy w tkankę urbanistyczną. Przykładem takiego miasta jest miasto Poznań, posiadające pozostałości fortyfikacyjne z okresu XIX i XX w (Biesiadka J. et al, 2006). Rozplanowane na planie okręgu ciągle dominują w widoczny sposób w urbanistycznym układzie miasta. Skala nawet pojedynczego założenia fortecznego nie pozwala na zbagatelizowanie jej w procesie modernizowania i unowocześniania miasta. Niezaprzeczalnie wielkość obszaru zajmowanego przez poznańskie forty stanowią obszar dotykający problematykę w skali już nie tylko architektonicznej ale urbanistycznej.

Podczas rozwijania miasta jednym z głównych dokumentów wiodących i determinujących działania architektoniczne, inwestycyjne i planistyczne jest Studium Uwarunkowań i Kierunków Zagospodarowania Przestrzennego Miasta. Zarządzenie ma na celu ukształtowanie i przedstawienie celów oraz wizji przyszłej urbanistyki miejskiej. Jednym z nich w wizji miasta Poznań jest utworzenie miasta metropolitalnego opierającego rozwój na wiedzy (Spatial Management of City of Poznan, 2014). Próba osiągnięcia wymienionych $w$ dokumencie celów niezaprzeczalnie zderza się z problematyką pozostałości fortyfikacyjnych. Artykuł ma na celu przybliżyć problematykę kształtowania przyszłej urbanistyki miejskiej, która w swojej historii była związana z architektura militarna na przykładzie miasta Poznań i dzielnicy Malta. Omawiana część miasta zawiera w swojej strukturze pozostałości fortu III Graf Kirchbach (Biesiadka J. et al, 2006). Fort jest jednym z osiemnastu fortów, które stanowiły świadectwo obecności jednej z największych twierdzy w Polsce.

\section{CEL BADAŃ}

Obszar objęty opracowaniem badawczym znajduje się we wschodniej części miasta i jest bardzo dobrze skomunikowany z jego centralną częścią. Połączenie poznańskiego terenu fortu III z rynkiem odbywa się poprzez komunikowanie tych dwóch części miasta dzięki ulicom Małe Garbary, Estowskiego, Wyszyńskiego oraz Warszawskiej. Wymienione ulice biegną w poziomej linii zachodnio wschodniej, tworząc oś planistyczną złamaną przez ulicę Krańcową, która bezpośrednio łączy się z omawianym obiektem fortecznym. Tego typu układ urbanistyczny może zapoczątkować nowe możliwości planistyczne rozwoju miasta zgodnie z jego strategią poprzez poszanowanie wartości historycznych i ich świadectwa. Celem badań jest wykrycie możliwych kierunków działań z wykorzystaniem pozostałości pofortyfikacyjnych w dążeniu do rozwoju tkanki miejskiej, utworzenia atrakcyjnej oferty funkcjonalnej dla mieszkańców oraz wykreowania unikalnej strefy miejskiej. Wyniki badań mają za zadanie zaprzeczeniu lub potwierdzeniu tezy dotyczącej identyfikacji potencjalnych wytycznych projektowych wykorzystywanych w rewitalizowaniu obszarów o powierzchni ponad kilku hektarów.

Znacząca pozycja pozostałości poznańskiej architektury militarnej nie objawia się tylko w obecnych planach miasta, ale jest również ściśle związana z polską historią. Stanowi świadectwo dziejów historycznych. Jest autentycznym źródłem wiedzy architektonicznej, inżynieryjnej oraz technicznej. Inwentaryzacja fortu III (Piklikiewicz-Kęsicka I., 2017) wykazuje stan zachowania substancji zabytkowej umożliwiający poznanie i zrozumienie sztuki budowli militarnych. Oznacza to, że pozostałości forteczne niezaprzeczalnie stanowią już nie tylko element struktury miejskiej, ale powinny być odpowiednio przygotowane i udostępnione dla jak najszerszego grona odbiorców. Jednym z utrudnień w dążeniu do wizualnego podkreślenia i uatrakcyjnienia omawianych obiektów jest paradoksalnie jedna z ich najbardziej charakterystycznych cech architektonicznych - ukrycie. Celem zabudowań fortecznych było przede zamaskowanie obiektu przed wrogiem. Lokalizacja w terenie silnie zadrzewionym, przykrycie ziemią, wałami ziemnymi oraz murami nawet współcześnie scalają się wizualnie z krajobrazem. Jakiekolwiek działania podejmowane w celu fizycznego odsłonięcia obiektu koliduja z potrzebą zachowania wałów fortecznych oraz nasypów ziemnych, które również stanowią element cennego założenia objętego ochroną zabytku. Ingerencja w ich układ z pewnością stanowiłaby działanie destrukcyjne i zaburzające całość autentycznego założenia fortecznego. Tym bardziej angażowanie już nie tylko samego obiektu w działania rewitalizacyjne i konserwatorskie, ale również założenia planistyczne obejmujące układy komunikacyjne oraz kompozycyjne wydają się być właściwym 
krokiem w celu aktywnego włączenia pozostałości obiektów cennych historycznie w rozwijającą się tkankę miejską.

\section{METODOLOGIA BADAWCZA}

W celu zobrazowania problematyki badawczej wykorzystano metodykę badania analizy i konstrukcji logicznej (Niezabitowska E., 2014). Posłużyła ona do graficznego przeanalizowania poznańskiego obszaru Malta pod względem wybranych czynników urbanistycznych i planistycznych. Badania głównie skupiają się na zdiagnozowaniu kierunków urbanistycznych wykorzystujących obiekt zabytkowej architektury militarnej fortu III. Opracowywany obszar poddano badaniom walkthrough, które umożliwiły realizację wizji lokalnych i inwentaryzacyjnych. Potwierdzeniu słuszności poszukiwanych działań posłużyły badania historyczne i literaturowe. Artykuł przedstawia przykłady obiektów i założeń urbanistycznych, których historyczna geneza została wykorzystana w celu zaspokojenia potrzeb współczesnego użytkownika. Wybrane przykłady historyczne stanowią dzieła o unikalnej genezie, która zagwarantowała im utworzenie niepowtarzalnej nowej przestrzeni miejskiej. Oryginalność przedstawionych obiektów nie wynika z subiektywnych preferencji projektantów, ale stanowi ponowne wykorzystanie architektury, która dawniej pełniła istotne funkcje i stanowi realne świadectwo autentycznego myślenia architektonicznego w przeszłości. Poprzez nadanie jej nowej funkcji i przystosowanie do współczesnej przestrzeni urbanistycznej utworzono miejsca, których uwarunkowania historyczne zapewniają im oryginalność i brak fałszywego naśladownictwa.

\section{OBSZAR OBJĘTY BADANIEM. WYNIKI BADAŃ}

Teren fortu III zlokalizowany jest w poznańskim rejonie Malta, przy ulicy Krańcowej 81. Obiekt znajduje się na terenie Nowego Zoo. Obszar przestrzenny objęty jest miejscowym planem zagospodarowania przestrzennego (Poznan City Council , 2002). Dokument uwzględnia adaptację fortu na funkcje usług rekreacyjnych lub na potrzeby ogrodu zoologicznego. Wszelkie planowane zmiany wymagają uzgodnienia z organem ochrony zabytków. Miejscowy plan umożliwia wykorzystanie obiektu fortecznego na nowe funkcje. Rozległy teren zajmowany przez fort osłonięty jest terenami zieleni niskiej i wysokiej, co również wynika z jego lokalizacji na obszarze chronionym Natura 2000. Ingerencja w zieleń w celu odsłonięcia i podkreślenia bryły fortu jest praktycznie niemożliwa. Oprócz niezbędnych działań w celu usunięcia zieleni destrukcyjnej, fort powinien pozostać w swojej naturalnej osłonie. Zabiegi mające na celu uatrakcyjnienie przestrzeni fortecznej oraz sąsiadującej z zabytkiem należy zatem odnieść nie tylko do samego obiektu ale również do szerszego zakresu opracowania planistycznego.

Przeprowadzone analiza urbanistyczna omawianego obszaru pod względem użytkowania terenu potwierdza urbanistyczne wyalienowanie fortu III z funkcjonalnie powiązanych ze sobą terenów. Oprócz lokalizacji obiektu na terenie usługi jaką pełni Zoo, zabytek odgrodzony jest od najbliższych terenów zabudowy mieszkaniowej, usługowej i rekreacyjnej. Obiekt otoczony zielenią nieurządzoną nie zachęca potencjalnych użytkowników. Uatrakcyjnienie ulicy Krańcowej i komunikacji pieszej oraz rowerowej z obszarem sportowym Malta mogłoby stanowić odpowiedni kierunek w celu urbanistycznego podkreślenia chronionego zabytku. Działanie takie korzystnie wydłużyłoby obszar rekreacyjny w tej części miasta z dodatkową funkcją kulturową, którą realizowałby fort III. Bliskie sąsiedztwo Jeziora Maltańskiego oraz obiektów sportowych miałoby szansę kontynuacji na płaszczyźnie urbanistycznej. Obecnie teren skomunikowany jest $z$ fortem III również poprzez sezonowo funkcjonująca kolejkę Maltanka.

Korzyści płynące z otoczenia badanego obszaru poprzez duże przestrzenie zieleni wysokiej i niskiej nie są wystarczającą wykorzystywane. Badania inwentaryzacyjne wykazują działanie zieleni destrukcyjnej na terenie obiektu fortu III Graf Kirchbach. Elementy roślin i drzew, które rosną niekontrolowanie ingerują w zabytkową substancję obiektu i w konsekwencji powodują między innymi jego pękanie. Wymagana jest nadzorowana kontrola roślinności na terenie obiektu. W ramach istniejących ciągów pieszych i drogowych należałoby rozważyć możliwość wprowadzenia elementów małej architektury. Taki zabieg z pewnością sprzyjałby zintensyfikowaniu użytkowania tej części miasta 
oraz wzbogacił go o wartości wizualne. Lokalizacja ławek i siedzisk umożliwiłaby odpoczynek wzdłuż trasy Jeziora Maltańskiego prowadzącej do fortu oraz wzdłuż ulicy Krańcowej. Uatrakcyjnienie wizualne omawianej ulicy powinno również być związane z poszerzeniem jej oferty funkcjonalnej. Wniosek ten potwierdza Studium Uwarunkowań i Kierunków zagospodarowania Przestrzennego Miasta Poznania (Spatial Management of City of Poznan, 2014) na załączniku rysunkowym obejmującym funkcję usługową i sportową lokalizowaną w zieleni (Rys. II.2.2.4/4). Realizacja wymienionych działań z pewnością wpłynęłaby korzystnie na teren otaczający fort i stanowiła urbanistyczne preludium naprowadzające do chronionego zabytku.

Obszar sąsiadujący z fortem III zawierający się w rejonie Jeziora Maltańskiego oceniono na dobrze skomunikowany. Dojazd do zabytku jest umożliwiony poprzez ulicę Krańcową zarówno poprzez ruch pojazdów osobowych jak i komunikację publiczną autobusową (linia nr 184). Wzdłuż omawianej ulicy poprowadzona jest dwukierunkowa ścieżka rowerowa. Zapewniona jest również bezkolizyjna i wydzielona ścieżka piesza. W wyniku badań obszaru nie zaobserwowano występowania elementów umożliwiających zatrzymanie i odpoczynek potencjalnego użytkownika obiektu zabytkowego, które mogłyby zapewnić wcześniej omawiane ławki lub siedziska.

Badany fragment obszaru Malta posiada w opracowywanym obrębie nie tylko fort jako jedyny element chroniony o wartości historycznej. Założenia planistyczne związane z projektowaniem poznańskiej architektury militarnej pierścienia zewnętrznego i wewnętrznego dominowały i hierarchizowały urbanistykę XIX i XX wiecznego miasta. Obszar lokalizowania fortów oraz budowli z nimi związanych okalał i tworzył granicę Poznania, która współcześnie została przebita poprzez rozwój urbanistyczny determinowany potrzebami mieszkaniowymi, komunikacyjnymi, gospodarczymi i ekonomicznymi. Pomimo intensywnej rozbudowy miasta pewne elementy tych wielkich założeń zachowały się do dzisiejszego dnia. Oprócz obiektów fortecznych przetrwały również bastiony, pomniki i budowle symbolizujące wolność. Pozostałości omawianych obiektów dają możliwość stworzenia spójnego założenia urbanistycznego, które po połączeniu ze sobą mogłyby ukształtować obszar eksponujący omawiane obiekty wartościowe historycznie.

Analiza badanego obszaru pod względem intensywności użytkowania ściśle uzależniona jest od możliwości całorocznego użytkowania obiektów zlokalizowanych na tym terenie. Z badań wynika, że elementem naznaczonym najsilniejszą eksploatacją są przestrzenie publiczne z funkcjami usługowymi lub rekreacyjnymi. Centrum handlowo - usługowe takie jak Galeria Malta, Stary Rynek oraz Termy Maltańskie są miejscami, które stanowią atrakcję dla potencjalnych użytkowników obszaru Malta. Stary Rynek został objęty obszarem badań z powodu jego dobrej komunikacji względem opracowywanego terenu oraz faktu, że stanowi jedną z głównych atrakcji turystycznych miasta. Jest miejscem, które powinno stanowić początek założenia urbanistycznego mającego na celu rewitalizację i urbanizację terenu fortu III.

Badania współczesnego planu urbanistycznego terenu Malta wykazały nałożenie dwóch siatek modelowych kształtujących obowiązującą komunikację i zabudowę tego obszaru. Pierwsza siatka urbanistyczna - promienista wynika z planów historycznych, które silnie odznaczyły się we współczesnym układzie miasta. Druga siatka przypominająca układ ortogonalny jest efektem działań dążących do skomunikowania miasta między jego poszczególnymi częściami oraz sąsiednimi aglomeracjami. Obszar Malta znajduje się na osi komunikacyjnej między centrum miasta oraz drogą prowadzącą do Swarzędza oraz trasą nr 92. Jest to teren bardzo atrakcyjny pod względem lokalizacji, komunikacji oraz walorów krajobrazowych.

Teren fortu III z lokalizacją w poznańskim rejonie Malta cechuje się dobrą lokalizacją i skomunikowaniem z centrum miasta oraz pobliskimi aglomeracjami. Jest to istotny czynnik w procesie scalania zabytkowego obszaru chronionego z istniejącą siatką urbanistyczną miasta. Badany obszar posiada cechy dające możliwości wzbogacenia obecnej oferty funkcjonalnej miasta w oparciu o wartości historyczne. Wymaga to jednak nie tylko rewitalizacji samego zabytku ale również terenów go otaczających. Silne natężenie sąsiednich terenów zielonych powinno zostać zagospodarowane i zmodernizowane w celu utworzenia atrakcyjnej wizualnie i funkcjonalnie przestrzeni dla użytkowników oraz turystów. Obszar działań należy poszerzyć tak aby płynnie zjednoczyć go z centrum miasta za pomocą realizacji o kompozycjach osiowych z elementami małej architektury oraz dominantami. Teren 
powinien być różnorodny funkcjonalnie aby mógł spełnić zapotrzebowania jak największej liczby odbiorców (użytkowników). Dążenie do równowagi poprzez kształtowanie terenów rekreacyjnych, mieszkaniowych, usługowych oraz przestrzeni publicznych, rozłożonych na osi, której elementem wieńczącym byłby fort III z pewnością stanowiłoby jeden z procesów dążących do odpowiedzialnej urbanizacji.

\section{POTENCJAŁ OBSZARU FORTU III}

Wynika badań przedstawiają atrakcyjność terenu fortecznego zlokalizowanego w rejonie Malta. Doskonała komunikacja publiczna zapewnia dostęp użytkownika do obiektu i terenu go otaczającego. Bezpośrednie sąsiedztwo z terenami rekreacyjnymi w obrębie Jeziora Maltańskiego oraz możliwości jakie dają rozległe tereny zieleni mogą stanowić fundament do stworzenia atrakcyjnej i unikalnej przestrzeni. Po odpowiednim jej przygotowaniu i oddaniu do użytkowania mogłaby stworzyć nowe warunki kreujące proces doprowadzenia zabytkowego fortu III do nowoczesnego wykorzystania. Unikalna architektura militarna, która zachowana została w postaci umożliwiającej odczytanie jej pierwotnego przeznaczenia oraz całego procesu projektowego stanowi rzetelne świadectwo wojskowej inżynierii projektowej. Niezaprzeczalnie jest istotnym źródłem wiedzy o architekturze i budownictwie. Zagospodarowana przez nią przestrzeń nie angażuje wyłącznie budowli i pomieszczań ale również precyzyjne formowanie i kształtowanie terenu oraz zieleni. To olbrzymie założenie przestrzenne daje wiele możliwości dla współczesnego projektowania w zakresie rewitalizowania obszarów zabytkowych. Bliska lokalizacja centrum miasta oraz atrakcyjne pod względem funkcjonalnym tereny sąsiadujące $z$ fortem III zapewnia napływ potencjalnych użytkowników w ten rejon miasta. Wśród otaczających terenów mieszkaniowych, usługowych oraz rekreacyjnych obiekt forteczny mógłby stanowić element harmonizujący program funkcjonalny obszaru Malta i wzbogacić jego mieszkańców oraz turystów o unikatowy obszar kulturowy.

\section{PRZYKŁADY REWITALIZACJI OBIEKTÓW WIELKOPOWIERZCHNIOWYCH}

Badania literaturowe mają za zadanie przywołanie przykładów rewitalizacji obszarów urbanistycznych obejmujących tereny, które angażowały obszary o dużej powierzchni $\mathrm{i}$ istotnie ingerowały w strukturę planistyczną miasta. Pełniąc w przeszłości istotne funkcje związane z różną działalnością na przykład obronną lub transportową przestały spełniać swoje pierwotne przeznaczenie w wyniku postępu cywilizacyjnego oraz technicznego. Ich rola w płaszczyźnie funkcjonalnej definitywnie się zakończyła w obliczu potrzeb użytkowych współczesnych mieszkańców danej miejscowości. Obszar, który zajmowały uległ transformacji w celu spełnienie warunków strategii rozwojowych planowania przestrzennego. Wybrane przykłady omawianych obszarów prezentują wykorzystywanie potencjałów pozostałości architektonicznych o dużej skali i przekształcenie ich do użytku publicznego w celu ukształtowania niepowtarzalnej przestrzeni służącej współczesnej ludzkości.

High Line Park [Cilento K., 2009] w Nowym Jorku stanowi rzeczywisty przykład realizacji zgodnie z zasadami odpowiedzialnej urbanizacji. Opisywane założenie jest parkiem rozciągniętym na długość blisko 2,5 km i podniesionym na wysokość około $9 \mathrm{~m}$ powyżej głównej płaszczyzny ruchu poziomego. Obiekt został zbudowany w $1930 \mathrm{r}$ w konstrukcji stalowej i realizował funkcję transportu kolejowego na odcinku $21 \mathrm{~km}$. Po upadku towarzystw kolejowych wyburzono południową część trasy i przestano z niej definitywnie korzystać. High Line stanowi ciekawe założenie architektoniczne pod względem przestrzennym, które nie tylko charakteryzuje się podniesieniem płaszczyzny ruchu ale również rozplanowaniem między okolicznymi budynkami. Pozostałości obiektu z czasem zaczęły obrastać w niekontrolowaną zieleń i stanowić element generujący negatywną i niebezpieczną przestrzeń publiczną. W 2003 roku w wyniku konkursu architektoniczno urbanistycznego wyłoniono koncepcję mającą na celu rewitalizację opisywanego obszaru, która proponowała utworzenie parku miejskiego. Autorami są projektanci z zespołów James Corner of Field Operations oraz Diller Scofidio + Renfro. Projekt obejmował utworzenie przestrzeni z elementami małej architektury oraz warunkami do podziwiania okolicznego krajobrazu. Główną atrakcję stanowią widoki na Rzekę Hudson oraz charakterystyczne wieżowce. Na obszarze zaprojektowano również strefy kultury na tymczasowe pokazy i przedstawienia. Projekt realizowano etapami w latach 2006-2014. Unikalne wykorzystanie 
przestrzeni oraz nadanie jej nowej funkcji, odpowiadającej potrzebom współczesnych użytkowników zaowocowało powstaniem tej charakterystycznej i niepowtarzalnej przestrzeni publicznej. Prawdopodobnie, gdyby nie uwarunkowania historyczne obiekt tego typu nigdy by nie powstał. Opisywany High Line Park stanowi dowód na możliwości wynikające z umiejętnego wykorzystania niefunkcjonalnego współcześnie obiektu poprzez nadanie mu nowych funkcji i zastosowanie wielkoskalowych narzędzi urbanistycznych. Projekt został zaplanowany i zrealizowany dla całości wielokilometrowego założenia, które zagwarantowało wykreowanie strefy spójnej i współgrającej z ciągle rozwijającą się urbanistyką miasta Nowy York.

Rewitalizacja danego obszaru rozkłada się na realizowanie działań na wielu płaszczyznach. Oprócz potrzeby sporządzenia architektonicznej i konserwatorskiej bazy danych na temat danego obszaru niezwykle cenna jest znajomość opinii i preferencji danej społeczności, która ma być docelowym odbiorcom planowanej inwestycji. Działania dążące do przywrócenia funkcjonalności obiektu lub zespołu obiektów rozłożonych na kilku lub kilkunastu hektarach jest wyzwaniem angażującym kreatywne i wielokierunkowe procesy projektowe. Natomiast jednym z wyznaczników świadczących o sukcesie danej architektury jest z pewnością jego prawidłowe i stałe funkcjonowanie. Oznacza to, że przede wszystkim celem rewitalizacji jest zapewnienie i przywrócenie użytkowania opracowywanego obszaru wraz z obiektami na nim zlokalizowanymi. Jedną z podstawowych funkcji miejskich niezbędnych do życia są funkcje mieszkaniowe wraz z dodatkowymi obszarami wspierającymi ich użytkowanie. Znakomitym przykładem obrazującym poruszaną problematykę jest projekt pracowni projektowej MVRDV, zlokalizowany w Mannheim (Niemcy). Inwestycja jest jeszcze niezrealizowana. Autorzy stworzyli 41 ha założenie projektowe dla rewitalizacji byłych baraków armii amerykańskiej (Lynch P., 2017). Idea projektu obejmuje zachowanie istniejących budynków militarnych oraz realizację dwóch nowoczesnych obiektów mieszkalnych wielorodzinnych. Działanie to gwarantuje zachowanie pierwotnego planu i układu urbanistycznego budynków armii przy jednoczesnym utworzeniu nowej struktury architektonicznej. Czynnikiem scalającym całość rewitalizowanego obszaru jest oś kompozycyjna, systematyzująca przestrzeń wyznaczając główny trakt komunikacyjny. Program funkcjonalny przewiduje różnorodną typologię mieszkalną wielorodzinną i jednorodzinną. Oprócz przestrzeni mieszkaniowych na terenie zlokalizowano obszary usługowe, handlowe oraz przestrzenie publiczne wspierające interakcję między przyszłymi mieszkańcami. Główna strefa handlowo usługowa umieszczona jest we wnętrzu wzgórza znajdującego się na osi kompozycyjnej.

Projekt pracowni MRDV znakomicie pokazuje sztukę projektowania z zachowaniem szacunku dla substancji historycznej oraz umiejętne prowadzenie dialogu architektonicznego pomiędzy historycznymi zabudowaniami a wprowadzaniem zupełnie nowej struktury. Dążenia do realizowania tego typu działań wymaga jednak wykorzystywania narzędzi urbanistycznych i spojrzenia na rewitalizowany obszar z szerszej perspektywy. Pojedyncze zabiegi, które nie są efektem wykonywania całościowego planu i nie uwzględniają kontekstu przynależnej współczesnej tkanki urbanistycznej, mogą nie gwarantować uzyskania pożądanych efektów rewitalizacyjnych. Przywrócenie efektywnego użytkowania opracowywanego obszaru, który nie zaspokaja potrzeb funkcjonalnych teraźniejszego i przyszłego użytkownika wymaga kompatybilnego planowania, dążącego do spojenia nowej i zabytkowej struktury urbanistycznej. W tym celu niezbędne jest odpowiedzialne urbanistyczne projektowanie i planowanie przestrzenne, uwzględniające nie tylko sam obszar rewitalizacji ale również teren go otaczający.

Jednym z największych poznańskich rewitalizowanych obszarów jest Park Cytadela o powierzchni 100 ha. Zlokalizowany w północnej części miasta, stanowi ciekawy przykład regenerowania obszarów wielkopowierzchniowych. Park powstał w obrębie powierzchni zawierającej pozostałości po forcie Winiary. Obszar ten stanowi niezwykle cenne dziedzictwo kulturowe, które zostało przekształcone i obecnie reprezentuje również dzieła sztuki oraz pomniki powstające od lat powojennych po ekspozycje współczesne. Pomimo wyburzeń fortu niektóre elementy zachowały się i zostały wykorzystane na powierzchnie prezentujące sztukę wojenną. Park stanowi również miejsce spoczynku między innymi weteranów powstania styczniowego, Bohaterów Polskich oraz żołnierzy brytyjskich. Oprócz całościowej przestrzeni ekspozycyjnej i upamiętniającej wydarzenia historyczne, teren stanowi oryginalną przestrzeń rekreacyjną aktywnie wykorzystywaną przez mieszkańców. Program funkcjonalny obszaru został zorganizowany w czterech sektorach tematycznych związanych z zabawą i sportem, kulturą, przyrodą oraz historią. W parku znajdują się place zabaw, siłownie, ogrody 
tematyczne, muzea oraz restauracja. Obszar stanowi ciekawą trasę dla rolkarzy oraz rowerzystów. Park Cytadela niewątpliwie stanowi oryginalne miejsce w przestrzeni miasta, zawierające naukę o historii Polski prezentując ją w prawdziwej pofortecznej przestrzeni. Dostosowanie tego obszaru do współczesnych potrzeb użytkowych mieszkańców z pewnością zostało zrealizowane. Całościowe, spójne i konsekwentne zagospodarowanie obszaru wraz z zachowaniem oryginalnych pozostałości zabytkowych oraz wprowadzeniem współczesnych elementów zagwarantowało powstanie wartościowej przestrzeni publicznej, która służy mieszkańcom oraz turystom.

\section{PODSUMOWANIE}

Wyniki badań potwierdzają tezę, że istnieją standardowe reguły projektowe wspomagające działania rewitalizacyjne wielkopowierzchniowe. Oparte na wydobywaniu potencjału nie tylko z samego obiektu zabytkowego ale również z terenu go otaczającego. Zastosowanie planowania przestrzennego obejmującego obszar buforowy łączący obszar rewitalizowany ze współcześnie rozwijającą się strukturą urbanistyczną, stanowi prawidłowy kierunek w przywracaniu funkcjonalności nieużytkowanego zabytku. Działanie takie wymaga przede wszystkim dokładnej analizy odpowiedniej wielkości powierzchni. W celu osiągnięcia pozytywnych wniosków wspierających przyszłe procesy projektowe obiekt badany powinien zostać opracowywany pod względem relacji z terenem z nim sąsiadującym. Wyznaczenie cech pozytywnych i negatywnych może stanowić podstawy w dążeniu do projektowania zrównoważonego oraz do odpowiedzialnej urbanizacji. Wiążę się z tym również umiejętność zachowania tożsamości danego miejsca przy nieuniknionej planowanej działalności architektonicznej (Jarecka-Bidzińska E., 2020). Takie działanie może być również katalizatorem do poprawy stanu lokalnej gospodarki i ogólnie pojętej poprawy jakości życia i funkcjonowania w danej strukturze osiedleńczej. W tym celu działania rewitalizacyjne powinny odpowiadać na obecne i przyszłe potrzeby mieszkańców. (Dudek M., 2019).

Dzieje cywilizacji pozostawiają swój zapis nie tylko w formach architektonicznych, ale również założeniach urbanistycznych I przestrzennych. Taki zapis stanowi niezaprzeczalnie element dziedzictwa kulturowego (Obuchowicz R., 2019). Rewitalizowanie zdegradowanych przestrzeni na nowe cele powinno być prowadzone $z$ poszanowaniem oraz podkreśleniem dziedzictwa kulturowego, które można uzyskać również poprzez wprowadzania nowych form architektonicznych. W celu uzyskania równowagi między nową a historyczną zabudową konieczne jest dogłębne zapoznanie się z pierwotnym założeniem terenu, jego układu funkcjonalnego oraz architektonicznego.

W kontekście rewitalizowania poznańskiego fortu III niezbędne jest rozważenie sposobu połączenia zabytku ze współczesną tkanką miejską. Działania zmierzające do zaangażowania fortu w program funkcjonalny miasta powinny odbyć się przy udziale kompleksowego wykorzystania potencjału terenu Malta. Przeprowadzone analizy omawianego obszaru wykazują znaczne walory przestrzenne, lokalizacyjne i funkcjonalne, które mogą stanowić fundament w procesach rewitalizacyjnych tego niezwykle cennego obiektu architektury militarnej. Wykorzystanie dobrego skomunikowania obszaru fortecznego z rynkiem miejskim poprzez kompozycję osiową i naprowadzającą jest szansą również dla ulicy Warszawskiej oraz okolicznych mieszkańców do wzbogacenia tych terenów o dodatkowe funkcje usługowe i kulturowe. Obszar ten może zostać wykorzystany do wspierania miejskiego zjawiska flâneur (Paetzold H., 2008). Poznań pod względem walorów krajobrazu miejskiego nie ogranicza się wyłącznie do samego rynku, ale posiada równie ciekawe dzielnice, takie jak Ostrów Tumski z Katedrą, Śródka a także Malta. Wszystkie te dzielnice zlokalizowane są na osi prowadzącej od terenu centrum do fortu III. Poprawa funkcjonalna oraz wizualna realizowana na tej trasie mogłaby stać się płaszczyzną miejskich przechadzek z możliwością ich kontynuacji na terenie rekreacyjnym w obszarze Jeziora Maltańskiego. Zaangażowanie użytkownika korzystającego z atrakcji ścisłego centrum poprzez ruch w opisywanej osi, wzbogaconej o małą architekturę oraz funkcje usługowe stanowiłoby nieocenioną strategię w procesie rewitalizowania fortu III Graf Kirchbach. Pozostałości architektury militarnej to nie tylko fizyczne resztki murów, ścian i bastionów. To bezcenne źródło autentycznej wiedzy architektonicznej oraz świadectwo historii, które powinno być pielęgnowane i udostępnione do poszerzania wiedzy oraz jej rozwijania. W przypadku założeń wielkopowierzchniowych to odpowiedzialna urbanizacja decyduje o przetrwaniu i jakości naszej przeszłości, a w tym wypadku również przyszłości. 


\section{BIBLIOGRAPHY}

Act dated 23rd of April 2002, Act No LXXXV/982/III/2002 of the Poznan City Council (in Polish).

Act dated 23rd of September 2014, Studium Uwarunkowań I Kierunków Zagospodarowania Przestrzennego Miasta Poznań (Study of Conditions and Directions of Spatial Management of City of Poznan).

BiesiadkaJ., Gawlak A., Kucharski S., Wojciechowski M.: 2006, Twierdza Poznań, Wydawnictwo Rawelin, Poznań.

Cilento K., 2009, The New York High Line officially open, archdaily.com.

Dudek M., 2019, Revitalisation of the brownfield land on the example of the Former Bethlehem Steel, Space \& Form / Przestrzeń I forma no 37/2019, Wydawnictwo Uczelniane Zachodniopomorskiego Uniwersystetu Technologicznego w Szczecinie, pp. 99-112.

Jarecka-Bidzińska E., 2020, The urban development and preserving place identity as a result of effective revitalisation of Barcelona's El Raval district, Space \& Form / Przestrzeń I forma no 43/2020, Wydawnictwo Uczelniane Zachodniopomorskiego Uniwersystetu Technologicznego w Szczecinie, pp. 163-178

Lynch P.: 2017, MVRDV's 'H-O-M-E' Converts Former Army Barracks into Mixed-Use District in Mannhei, archdaily.com.

MVRDV's 'H-O-M-E' www.archdaily.com/806685/mvrdvs-h-o-m-e-converts-former-army-barracks-into-mixeduse-district-in-mannheim, dostęp 14.01.2019

Niezabitowska E., 2014, Metody I techniki badawcze w architekturze, Wydawnictwo Poltechniki Śląskiej, Gliwice.

Obuchowicz R., 2019, Industry heritage as tourist attraction - existing resources and possibilities of thei use on the example of selected objects of Szczecin, Space \& Form/ Przestrzeń I forma no 38/2019, Wydawnictwo Uczelniane Zachodniopomorskiego Uniwersytetu Technologicznego w Szczecinie, pp. 89-110.

Paetzold H., 2008, Experiencing Urban Architecture. The Politics of Strolling in the Vien of Walter Banjamin, in What is Architecture?, manggha, Kraków, pp. 117-165.

Piklikiewicz-Kęsicka I., 2017, Architectural features of military architectural structures in Poznań, Architecture Civil Engineering Environment, Wydawnictwo Politechniki Śląskiej, Gliwice, pp. 47-56.

The New York High Line officially open https://www.archdaily.com/24362/the-new-york-high-line-officiallyopen, dostęp 21.06.2019

Żywiałkowski M., 2016, High Line - od Alei Śmierci do modnej okolicy, Transport Publiczny. 


\section{AUTHOR'S NOTE}

Graduate of the Silesian University of Technology (2013) and Poznan University of Technology (2015). Field of research: military architecture and workplace architecture. Opening of the doctoral thesis (2018) with the title: The role of creative supplementary space in office workplaces (supervisor: prof. dr hab. Inż. Arch. Agata Bonenberg). More important publications: : Innovative office workplaces (ACEE 2021), An easy lie of office architecture (2020), Konflikt społeczny, architektoniczny $i$ krajobrazowy wokół przetrwania oraz zachowania obiektu fortecznego Fortu III Graf Kirchbacha (2019). The author uses the architect's work to extract information for research on improving the quality of life and work using architectural tools.

\section{O AUTORZE}

Absolwentka Politechniki Śląskiej (2013) i Politechniki Poznańskiej (2015). Asystent na Wydziale Architektury Politechniki Poznańskiej. Obszar badań: architektura militarna i projektowanie miejsc pracy. Otwarcie przewodu doktorskiego (2018) o tytule: Rola kreatywnej przestrzeni suplementarnej w miejscach pracy biurowej (promotor: prof. dr hab. Inż. Arch. Agata Bonenberg). Ważniejsze publikacje: Innovative office workplaces (ACEE 2021), An easy lie of office architecture (2020), Konflikt społeczny, architektoniczny i krajobrazowy wokół przetrwania oraz zachowania obiektu fortecznego Fortu III Graf Kirchbacha (2019). Autorka wykorzystuje pracę architekta w celu pozyskiwania informacji do badań nad polepszaniem jakości życia i pracy przy pomocy narzędzi architektonicznych.

Contact | Kontakt: izabela.piklikiewicz-kesicka@put.poznan.pl 